\title{
PENINGKATAN PENGETAHUAN DAN KETRAMPILAN KELOMPOK WANITA TANI DALAM MENGOLAH VARIASI PRODUK IKAN LELE MELALUI PROGRAM KULIAH KERJA NYATA PEMBELAJARAN PEMBERDAYAAN MASYRAKAT
}

\section{IMPROVEMENT OF KNOWLEDGE AND SKILLS OF FARMER WOMEN GROUPS TO PROCESSING OF CATFISH PRODUCTS VARIATIONS THROUGH COMMUNITY SERVICE PROGRAM OF COMMUNITY EMPOWERMENT LEARNING}

\author{
${ }^{1)}$ Suwarsito, ${ }^{2)}$ Hindayati Mustafidah, ${ }^{3)}$ Ratna Kartikawati \\ ${ }^{1)}$ Program Studi Pendidikan Geografi, FKIP, ${ }^{2}$ Program Studi Teknik Informatika, Fakultas Teknik, \\ 3) Program Studi Pendidikan Kewarganegaraan, FKIP, Universitas Muhammadiyah Purwokerto \\ Jl. Raya Dukuhwaluh PO Box 202 Purwokerto \\ ito_warsito@yahoo.co.in
}

\begin{abstract}
ABSTRAK
Kegiatan pengabdian pada masyarakat melalui Program Kuliah Kerja Nyata Pembelajaran Pemberdayaan Masyarakat (KKN PPM)bertujuanuntuk meningkatkan pengetahuan dan ketrampilan kelompok wanita tani dalam mengolah berbagai variasi produk ikan lelemenggunakan good manufacturing practicess.Kegiatan KKN PPM dilaksanakan di Desa Limpakuwus, Kecamatan sumbang, Kabupaten Banyumas selama 32 hari. Metode pelaksanaan program KKN-PPM adalah partisipasi aktif, pelatihan, dan pendampingan. Kelompok sasaran program KKN PPM adalah Kelompok Wanita Tani Mugi Rahayu di Desa Limpakuwus yang berjumlah 20 orang. Kelompok sasaran berpartisipasi aktif dengan mahasiswa KKNdandosen pembimbing lapangan dalam melaksanakan kegiatan KKN PPM. Kegiatan pelatihan diawali dengan penyampaian materi, dilanjutkan dengan praktek langsung, dan pendampingan selama program KKN-PPM berlangsung. Kegiatan pelatihan meliputi pengolahan dan pengemasan variasi produk olahan ikan lele, meliputi abon, nugget, bakso, kerupuk, dan keripik crispy kulit lele. Hasil kegiatan pengabdian masyarakat melalui Program KKN PPM telah dapat meningkatkan pengetahuan dan keterampilan kelompok wanita tani Mugi Rahayu di Desa Limpakuwus dalam mengolah variasi produk ikan lelemenggunakan good manufacturing practicess. Produk-produk olahan ikan lele yang dihasilkan meliputi abon, nugget, bakso, kerupuk, dan keripik crispy kulit lele.
\end{abstract}

Kata Kunci : Kelompok Wanita Tani, KKN PPM, Pengetahuan Dan Keterampilan, Variasi Produk Olahan Ikan Lele

\begin{abstract}
Community service activities through the Community Service Program of Community Empowerment Learning (KKN PPM) aimed to increase the knowledge and skills of farmer women group in processing of catfish products variations using good manufacturing practicess. The program implementationmethod using active participation, training, and mentoring. The program activities were conducted in Limpakuwus, Sumbang, Banyumas District for 32 days. Farmer Women Group of Mugi Rahayu with 20 members were involved in the program. Farmer Women Group actively participates with students accompanied by lecture carry out program activities together. The training activities initiated with lectures, followed direct practice, and mentoring during implementation program. The training consist of processing and packaging
\end{abstract}


Suwarsito, Hindayati Mustafidah, Ratna Kartikawati Peningkatan Pengetahuan Dan Ketrampilan Kelompok Wanita Tani Dalam Mengolah Variasi Produk Ikan Lele Melalui Program Kuliah Kerja Nyata Pembelajaran Pemberdayaan Masyrakat

of catfish products variations, namely abon, nugget, meatballs, crackers, and catfish crispy skin chips. The results of community service activities through the KKN PPM Program have been able to improve the knowledge and skills of Mugi Rahayu farmer group in Limpakuwus Village in processing of catfish products variations using good manufacturing practices. The processed catfish products produced include abon, nugget, meatballs, crackers, and catfish crispy skin chips

Key words: Women Farmers Group, KKN PPM, Knowledge And Skills, Catfish Products Variations

Submitted: 30 Agustus 2018 Revision: 7 September 2018 Accepted : 25 September 2018

\section{PENDAHULUAN}

Desa Limpakuwus adalah salah satu desa di wilayah Kecamatan Sumbang Kabupaten Banyumas yang terletak di pinggiran pedesaan bagian utara dengan luas wilayah 214,562 ha. Desa Limpakuwus sebagian besar wilayahnya terdiri atas lahan pekarangan, perkebunan, lahan sawah tadah hujan, sawah beririgasi, dan kolam ikan.Di wilayah tersebut banyak terdapat beberapa sumber mata air alami yang mengalir ke sungai-sungai kecil di desa tersebut. Sumbersumber mata air tersebut cukup melimpah dan mengalir sepanjang tahun. Potensi desa yang demikian mampu memacu berkembangnya agribisnis pertanian termasuk di dalamnya sub sektor perikanan. Komoditas pertanian utama yang diusahakan oleh petani adalah padi, jagung, pepaya, hortikultura, nilam, kacangkacangan, dan umbi-umbian dalam sistem pertanaman tumpangsari, sedangkan komoditas utama perikanan meliputi ikan lele, mujaer, gurameh, nila, dan melem.

Di Desa Limpakuwus terdapat Kelompok Wanita Tani Mugi Rahayu yang anggotanya terdiri dari ibu rumah tangga.Sebagian kaum wanita terutama ibu rumah tangga di desa tersebut menganggur dan tidak memiliki kegiatan yang produktif. Ada beberapa ibu rumah tangga yang menjadi buruh tani namun penghasilannya tidak menentu. Hanya terdapat sedikit ibu rumah tangga yang mempunyai kegiatan produktif seperti pembuatan kripik tempe sagu dan kripik singkong dan tales. Tidak mengherankan jika
Desa Limpakuwus termasuk desa kategori miskin, karena sebagian besar kepala keluarganya hanya menjadi petani kecil dan buruh tani, sementara sebagian besar ibu rumah tangganya tidak mempunyai penghasilan tambahan untuk mencukupi kebutuhan rumah tangganya.

Melalui program KKN PPM, di Desa Limpakuwus telah dikembangkan budidaya ikan lele secara intensif dengan sistem bioflok. Tujuan pengembangan budidaya ikan lele tersebut untuk meningkatkan produksi ikan lele di Desa Limpakuwus. Hasil budidaya ikan lele tersebut diharapkan dapat meningkatkan perekonomian masyarakat Desa Limpakuwus.Harga jual ikan lele hasil budidaya saat ini relatif rendah berkisar antara Rp 14.000 - Rp 15.000. Hal ini menyebabkan keuntungan dari usaha budidaya ikan lele juga rendah. Oleh karena itu, perlu dilakukan pengolahan variasi produk ikan lele agar nilai jualnya meningkat. Namun pengetahuan dan ketrampilan masyarakat Desa Limpakuwus terutama kaum wanita dalam mengolah variasi produk ikan lele masih rendah.Hal ini menjadi kendala untuk mengembangkan usaha pengolahan variasi produk ikan lele di Desa Limpakuwus.

Berdasarkan uraian di atas, program KKN-
PPM bertujuan untuk meningkatkan
pengetahuan dan ketrampilan kelompok
wanita tani Mugi Rahayu dalam mengolah
variasi produk ikan lelemenggunakan good
manufacturing practicess. Teknologi good
manufacturing practicess mampu menghasilkan
produk-produk olahan ikan lele yang higienis tanpa

JPPM ISSN: 2549 - 8347 (Online)

ISSN: 2579 - 9126 (Print)

Vol. 2 No. 2 September 2018 
Suwarsito, Hindayati Mustafidah, Ratna Kartikawati Peningkatan Pengetahuan Dan Ketrampilan Kelompok Wanita Tani Dalam Mengolah Variasi Produk Ikan Lele Melalui Program Kuliah Kerja Nyata Pembelajaran Pemberdayaan Masyrakat

tambahan bahan kimia sehingga aman dikonsumsi.Selain itu, teknologi pengolahan variasi produk ikan lele ini menerapkan konsep zero waste process(Nuraenahet al., 2016; Widyatami dan Wiguna, 2016). Dengan konsep zero wasteprocess ini, semua bagian tubuh ikan lele mulaidari daging, kulit, dan tulang dimanfaatkan untuk bahan olahan produk ikan. Daging ikan lele dimanfaatkan untuk bahan pengolahan abon, bakso, dan nugget ikan (Rijal, 2017; Putra dan Ismail, 2018). Bagian kulit dan tulang ikan lele dimanfaatkan untuk bahan pengolahan aneka crispy kulit ikan dan kerupuk ikan (Wida dan Anam, 2016). Selain itu, kepala dan tulang ikan serta jeroan ikan dimanfaatkan untuk pembuatan pakan ikan sebagai sumber protein, lemak, dan mineral pakan. Hasil-hasil olahan produk ikan lele selanjutnya dikemas menggunakan vacuum packing. Teknologi pengemasan menggunakan vacuum packing menghasilkan produk olahan ikan yang lebih menarik, renyah, dan tahan lama.

Melalui usaha pengolahan variasi produk ikan lele yang melibatkan peran mahasiswa dan kelompok wanita tani, diharapkan dapat meningkatkan kesejahteraan keluarga di Desa Limpakuwus.

\section{METODE KEGIATAN}

Kegiatan KKN PPM yang dilakukan adalah pemberdayaan masyarakat berbasis riset untukmeningkatkan pengetahuan dan ketrampilan kelompok sasaran dengan cara alih teknologi melalui kegiatan pelatihan,praktik langsung, dan pendampingan.Metode pelaksanaan program KKN-PPM adalah partisipasi aktif, pelatihan, dan pendampingan. Kelompok sasaran program KKN PPM adalah Kelompok Wanita Tani Mugi Rahayu di Desa Limpakuwus yang berjumlah 20 orang. Kelompok sasaran bersama mahasiswa KKN didampingi oleh dosen pembimbing lapangan melaksanakan kegiatan KKN PPM secara bersama-sama. Kegiatan pelatihan yang dilakukan adalah pengolahan dan pengemasan variasi produk olahan ikan lele, yaitu abon, nugget, bakso, kerupuk, dan keripik crispy kulit lele. Frekuensi kegiatan pelatihan dilakukan selama 3 kali, diawali dengan penyampaian materi, demonstrasi, dilanjutkan praktek langsung, dan pendampingan selama program KKN-PPM berlangsung.

Pelaksanaan kegiatan KKN-PPM melibatkan 30 mahasiswa dari program studiAgroteknologi, Agribisnis, Manajemen, Akuntansi, Teknik Informatika, Keperawatan, dan Hukum. Sebelum diterjunkan ke lokasi KKN, mahasiswa pesertaKKN PPM diwajibkan mengikuti pembekalan di kampus dengan materi teknologi pengolahan variasi produk ikan lele.

\section{HASIL DAN PEMBAHASAN}

Kegiatan pengabdian masyarakat melalui program KKN PPM ini telah berhasil dilaksanakan mulai dari kegiatan pelatihan, dilanjutkan praktik langsung dan pendampingan. Kegiatan pelatihan pengolahan variasi produk olahan ikan lele telah dilaksanakan sebanyak tiga kali yang diikuti oleh anggota kelompok wanita tani Mugi Rahayu. Materi pelatihan meliputi pemilihan bahan baku dan teknologi pembuatan abon, kerupuk, bakso, crispy kulit ikan, dan nugget ikan lele.Kegiatan pelatihan lain yang dilakukan adalah pengemasan produk olahan ikan lele menggunakan vaccum packing. Tahapan kegiatan pelatihan adalah penyampaian materi dan diskusi serta praktik langsung. Materi pelatihan meliputi pengenalan jenis-jenis kemasan produk, pembuatan design kemasan, dan tekonologi produk olahan ikan lele menggunakan vaccum packing. 
Setelah selesai kegiatan pelatihan dilakukan evalusi untuk mengukur tingkat pengetahuan peserta pelatihan menggunakan angket sederhana. Sepuluh orang peserta pelatihan diambil sebagai sampel/responden untuk mengetahui tingkat pengetahuan dan keterampilan sebelum dan sesudah mengikuti pelatihan. Hasil evaluasi kegiatan pelatihan aspek pengetahuan disajikan pada Tabel 1 .

Tabel 1. Hasil evaluasi peningkatan aspek pengetahuan peserta pelatihanpengolahan dan pengemasan variasi produk olahan ikan lele.

\begin{tabular}{llc}
\hline No. & Aspek pengetahuan & $\begin{array}{c}\text { Peningkatan } \\
(\%)\end{array}$ \\
\hline 1. & $\begin{array}{l}\text { Semua bagian tubuh } \\
\text { ikan lele dapat } \\
\text { digunakan untuk } \\
\text { membuat varisi produk } \\
\text { olahan }\end{array}$ & 25 \\
& $\begin{array}{l}\text { Cara pemilihan bahan } \\
\text { baku untuk membuat } \\
\text { variasi produk olahan } \\
\text { ikan lele }\end{array}$ \\
\hline Cara membuat variasi \\
produk olahan ikan \\
lele (abon, kerupuk, \\
bakso, crispy kulit \\
ikan, dan nugget ikan \\
lele)
\end{tabular}

Berdasarkan hasil evaluasi kegiatan pelatihan pada Tabel 1 menunnjukkan bahwa kegiatan pelatihan telah berhasil meningkatkan pengetahuan peserta pelatihan rata-rata $25 \%$. Kenaikan tingkat pengetahuan terrendah adalah pengetahuan caramembuatvariasi produk olahan ikan lele. Hal ini disebabkan peserta pelatihan sudah pernah mengikuti pelatihan pembuatan produk olahan ikan serupa. Namun pelatihan yang dilakukan melalui kegiatan KKN PPM ini lebih bervariatif produknya, tidak hanya membuat abon dan bakso ikan namun juga membuat produk lain seperti kerupuk, nugget, dan crispy kulitikan. Pengetahuan mengenai cara pengemasanprodukolahanikanlelemengalami peningkatan pengetahuan yang paling tinggi. Selama ini, pengemasan produk olahan makanan yang dilakukan oleh peserta pelatihan masih sederhana yaitu kemasan plastik sederhana. Setelah diberi pelatihan pengemasan produk menggunakan tekonologivaccum packing, pengetahuan peserta pelatihan meningkat. Sedangkan pengetahuan mengenai semuabagiantubuhikanleledapatdigunakanuntu kmembuatvariasiprodukolahan ikan lele juga meningkat. Peserta pelatihan sudah mengetuhi bahwa bagian tubuh ikan seluruhnya dapat digunakan untukmembuatvariasiprodukolahan ikan lele, namun bagian kepala dan tulang ikan selama ini dibuang saja.Setelah mendapatkan pelatihan, peserta pelatihan menjadi paham bahwa kepala dan tulang ikan dapat digunakan untuk bahan pembuatan kerupuk dan nugget ikan. Selain itu, kepala, tulang, dan jeroan ikanjuga dapat dimanfaatkan untuk pembuatan pakan ikan. Pengetahuan mengenai pemilihanbahanbakuuntukmembuatvariasiprod ukolahanikanlele juga meningkat. Peserta pelatihan menjadi lebih paham dalam memilih bahan baku yang baik untuk pembuatan abon, kerupuk, bakso, crispy kulitikan, dan nugget ikanlele.

Hasil evaluasi kegiatan pelatihan aspek keterampilan disajikan pada Tabel 2.

Tabel 2. Hasil evaluasi peningkatan aspek keterampilan peserta pelatihan pengolahan dan pengemasan variasi produk olahan ikan lele.

\begin{tabular}{llc}
\hline No. & \multicolumn{1}{c}{ Aspek Ketrampilan } & $\begin{array}{c}\text { Peningkatan } \\
(\mathbf{\%})\end{array}$ \\
\hline 1. & $\begin{array}{l}\text { Penyiapan bahan untuk } \\
\text { pembuatan abon, kerupuk, } \\
\text { bakso, crispy kulit ikan, } \\
\text { dan nugget ikan lele }\end{array}$ & 3,4 \\
\hline 2. & Pembuatan abon, kerupuk, & 20 \\
\hline
\end{tabular}

JPPM ISSN: 2549 - 8347 (Online)

ISSN: 2579 - 9126 (Print)

Vol. 2 No. 2 September 2018 
Suwarsito, Hindayati Mustafidah, Ratna Kartikawati Peningkatan Pengetahuan Dan Ketrampilan Kelompok Wanita Tani Dalam Mengolah Variasi Produk Ikan Lele Melalui Program Kuliah Kerja Nyata Pembelajaran Pemberdayaan Masyrakat

\begin{tabular}{lll}
\hline & $\begin{array}{l}\text { bakso, crispy kulit ikan, } \\
\text { dan nugget ikan lele }\end{array}$ & \\
\hline 3. & $\begin{array}{l}\text { Pengemasan variasi produk } \\
\text { olahan ikan lele }\end{array}$ & 100 \\
\hline \multicolumn{2}{c}{ Rata-rata } & 41,1 \\
\hline
\end{tabular}

Berdasarkan Tabel 2 terlihat adanya peningkatan keterampilan peserta pelatihan dalampengolahan dan pengemasan variasi produk olahan ikan. Kenaikan keterampilan peserta pelatihan terrendah adalah kemampuan menyiapkan bahan untuk pembuatan abon, kerupuk, bakso, crispy kulitikan, dan nugget ikanlele. Hal ini menunjukkan bahwa, peserta pelatihan sudah terbiasamenyiapkan bahan untuk pembuatan variasi produk olahan ikan lele sebelum mendapatkan pelatihan. Sedangkan peningkatan keterampilan paling tinggi adalah kemampuan pengemasanproduk olahanikanlele. Hal ini disebabkan karena adanya pendampingan yang intensif dari mahasiswa KKN PPM dan dosen pendamping kepada peserta pelatihan ketika praktik pengemasan produk berlangsung. Selain itu, peralatan untuk pengemasan produk menggunakan vaccum packingmudah dioperasikan. Keterampilan membuatvariasi olahan produk ikanlele peserta pelatihan juga meningkat walaupun peningkatannya tidak terlalu tinggi. Peserta pelatihan memiliki kemampuan yang lebih baik lagi dalam membuat variasi olahan produk ikanlele. Peserta pelatihan tidak hanya mampu membuat abon dan bakso ikan saja, namun juga sudah mampu membuatkerupuk, nugget, dan crispy kulitikan.

Secara keseluruhan, hasil kegiatan pelatihan pengolahan dan pengemasan produk olahan ikan lele telah meningkatkan keterampilan peserta pelatihan sebesar $41,1 \%$. Peningkatan keterampilan ini tidak lepas dari peran mahasiswa KKN PPM dan dosen pendamping yang selalu mendampingi peserta pelatihan ketika mempraktekkan pengolahan dan pengemasan variasi produk olahan ikan lele. Selain itu, penerapan metode pelatihan yang dilanjutkan praktek langsung dan pendampingan mempunyai pengaruh yang nyata terhadap peningkatan keterampilan peserta pelatihan. Kegiatan pelatihan dan praktik telah dilakukan sebanyak 3 kali sehingga keterampilan peserta pelatihan semakin meningkat.

Kegiatan pengabdian masyarakat melalui Program KKN PPM ini telah mampu meningkatkan pengetahuan dan keterampilan anggota kelompok tani Mugi Rahayu. Hasil kegiatan pengabdian pada masyarakat ini sesuai dengan hasil kegiatan yang dilakukan oleh Pratama et al. (2017) yang telah dapat meningkatkan pengetahuan dan keterampilanmasyarakat di wilayah yang terkena dampak penggenangan Waduk Jatigede Kecamatan Wado dalam pengolahan produk perikananyang sesuaistandar, sertasanitasidanhigienisdalam proses produksi. Selain itu, hasil kegiatan pengabdian pada masyarakat ini juga sama dengan hasil kegiatan pengabdian yang dilakukan oleh Nuraenahet al. (2016) yang telah dapat meningkatkan pengetahuan dan keterampilan dalam mengolah daging lele menjadi produk nugget, tulang ikan menjadi kerupuk tulang ikan, dan kulit ikan menjadi keripik kulit pada masyarakat pembudidaya lele di Kelurahan Sungai Jawi Kecamatan Pontianak Kota, Kota Pontianak. Selain itu, kegiatan pengabdian masyrakat ini juga telah menerapkan konsep zerro waste seperti yang telah dilakukan oleh Nuraenah et al. (2016) dan Widyatami dan Wiguna (2016). Kelebihan hasil kegiatan pengabdian masyarakat ini, selain semua bagian tubuh ikan dimanfaatkan untuk bahan pembuatan variasi produk olahan ikan lele, jeroan, kepala dan duri ikan dimanfaatkan untuk bahan pembuatan pakan ikan sebagai sumber protein dan mineral.

Evaluasi keberhasilan pelatihan juga dilakukan melalui kegiatan lomba memasak

JPPM ISSN: 2549 - 8347 (Online)

ISSN: 2579 - 9126 (Print)

Vol. 2 No. 2 September 2018 
Suwarsito, Hindayati Mustafidah, Ratna Kartikawati Peningkatan Pengetahuan Dan Ketrampilan Kelompok Wanita Tani Dalam Mengolah Variasi Produk Ikan Lele Melalui Program Kuliah Kerja Nyata Pembelajaran Pemberdayaan Masyrakat

variasi olahan ikan lele. Kegiatan lomba tersebut dilaksanakan bersamaan dengan kegiatan expo/pameran produk-produk olahan ikan lele. Lomba memasak variasi olahan ikan lele diikuti oleh 8 kelompok. Peserta lomba menyajikan berbagai variasi olahan ikan lele, berupa abon, kerupuk, bakso, crispy kulitikan, dan nugget ikanlele.Dari hasil kegiatan lomba memasak telah ditetapkan pemenang lomba, yaitu juara 1 dimenangkan oleh kelompok RW 6 (ketua Bu Saidem), juara 2 dimenangkan oleh kelompok RW 2 (ketua Bu Sri Wahyuni), dan juara 3 dimenangkan oleh kelompok RW 5 (ketua Bu Nuroto). Hasil kegiatan lomba menunjukkan bahwa anggota kelompok wanita tani di Desa Limpakuwus telah mampu membuat variasi produk olahan ikan lele tanpa didampingi lagi oleh mahasiswa KKN PPM dan dosen pendamping.

\section{SIMPULAN}

Hasil kegiatan pengabdian masyarakat melalui Program KKN PPMtelah dapat meningkatkan pengetahuan dan keterampilan kelompok wanita tani Mugi Rahayu di Desa Limpakuwus dalam mengolah variasi produk ikan lele menggunakan good manufacturing practicess. Produk-produk olahan ikan lele yang dihasilkan meliputi abon, kerupuk, bakso, crispy kulit ikan, dan nugget ikan lele. Hasil kegiatan pengabdian masyarakat masih perlu ditindaklanjuti dengan mengurus PIRT produk agar produk-produk olahan ikan lele yang dihasilkan mendapat kepercayaan masyarakat luas dan dapat dipasarkan sampai level nasional.

\section{UCAPAN TERIMA KASIH}

Penulis menyampaikan terima kasih kepada Direktorat Riset dan Pengabdian Masyarakat (DRPM) Kemenristekdikti yang telah memberikan dana untuk pelaksanaan Program KKN PPM ini.

\section{DAFTAR PUSTAKA}

Nuraenah,N., K. Novalina, dan I. M. Deviarni. (2016). IbM Pengembangan Produk Berbasis Lele Dengan Konsep Zero Waste Process di Kelurahan Sungai Jawi Kecamatan Pontianak Kota, Kota Pontianak. Jurnal Teknologi Pangan. 7 (2): 68-73.

Pratama, R. I., I. Rostini, dan N. Kurniawati. (2017). Pemberdayaan Masyarakat Melalui Peningkatan Keterampilan Produk Olahan Hasil Perikanan di Wilayah Yang Terkena Dampak Genangan Jatigede Kabupaten Sumedang. Jurnal Pengabdian kepada Masyarakat. 1 (1): 60 - 63.

Putra, D. E.dan A. M. Ismail. (2018). Diversifikasi Ikan Lele Menjadi Produk Olahan Pangan dalam Meningkatkan Kesejahteraan Petani Lele. The 7th University Research Colloquium 2018 STIKES PKU Muhammadiyah Surakarta. Halaman: 385-391.

Rijal, M. (2017). Diversifikasi Produk Olahan Ikan bagi Ibu-Ibu Nelayan di Dusun Mamua Kabupaten Maluku Tengah. Jurnal Biology Science \& Education. 6 (2): 159-170.

Susan dan A. Sophia. (2016). Pemberdayaan Masyarakat pada Kelompok Ternak Lele "Pangeran Jalon" di Desa Losarang, Indramayu. Jurnal CARE. Jurnal Resolusi Konflik, CSR, dan Pemberdayaan, 1 (1): 50-56

Wida, E.R. dan C. Anam. (2016). Peningkatan Kualitas dan DiversifikasiProduk Olahan Ikan Lele. E-Dimas (EducationPengabdian kepada Masyarakat). Vol. 7 (02): 27 - 38. 
Suwarsito, Hindayati Mustafidah, Ratna Kartikawati

Peningkatan Pengetahuan Dan Ketrampilan Kelompok Wanita Tani Dalam Mengolah Variasi Produk Ikan Lele Melalui Program Kuliah Kerja Nyata Pembelajaran Pemberdayaan Masyrakat

Widyatami,L. E. dan A.A. Wiguna. (2016).

Teknologi Pengolahan Ikan Lele secara

Zero Waste menjadi Produk Olahan

Kerupuk pada Ponpes Raden Rahmat

Sunan Ampel di Kabupaten Jember.

Seminar Hasil Penelitian dan

Pengabdian Masyarakat Dana BOPTN

Tahun 2016, Halaman: 283 - 288 